\section{Phenotypic and genotypic study on antibiotic resistance and pathogenic factors of Staphylococcus aureus isolates from small ruminant mastitis milk in South of Italy (Sicily)}

\author{
Alessio Parco, ${ }^{1}$ Giusi Macaluso, ${ }^{1}$ \\ Maria Foti, ${ }^{2}$ Maria Vitale, ${ }^{1}$ \\ Vittorio Fisichella, ${ }^{2}$ Marco Tolone, ${ }^{3}$ \\ Guido Ruggero Loria ${ }^{1}$
}

${ }^{1}$ Institute for Experimental Veterinary

Medicine of Sicily, “A. Mirri” Palermo;

${ }^{2}$ University of Messina; ${ }^{3}$ University of

Palermo, Italy

\begin{abstract}
Staphyloccoccus aureus is the major cause of mastitis in small ruminants in the Mediterranean farms causing severe losses to dairy industry. Antibiotic treatment has been the most common approach to control these infections. Aim of this study was to investigate antimicrobial resistance (AMR), virulence factors and biofilm-related genes of 84 Sicilian strains of $S$. aureus isolated from sheep and goats milk during two different periods $\delta \mathrm{T}_{1}(2006-2009)$ and $\delta \mathrm{T}_{2}$ (2013-2015). Kirby Bauer method and Polymerase Chain Reaction (PCR) were utilized to monitor AMR and related genes (mecA, tetK, tetM, ermA, ermC). Moreover, toxin genes (tsst-1, sea-see, seg-sej, and sep) and biofilm genes (bap, ica, sasC) were studied. Twenty-six isolates $(30.9 \%)$ showed multidrug resistance. The two groups showed similar results with exception for higher values of resistance for tilmicosin and lower for sulfamethoxazole and vancomycin of the second group. MecA gene was detected in one isolate. Tetracycline resistance was higher than $20 \%$, with an increase in $\delta \mathrm{T}_{2}$ group. Toxin genes were found in 5 isolates $(5.9 \%)$, belonging of $\delta \mathrm{T}_{2}$ group, while 57 of isolates $(67.8 \%)$ showed biofilm related genes. The high presence of multi-resistant isolates suggests the need of more responsible use of antibiotic therapy for the control of these infections.
\end{abstract}

\section{Introduction}

Sheep and goat farming still represents a valuable opportunity for labour and development of the Mediterranean rural areas of Sicily, Italy. Data from Italian Livestock
Register belonging to the Veterinary data base of Ministry of Health, show, on the year 2019, that small ruminant sector in Sicily is growing $(8.84 \%)$ with a total number of 800,000 heads distributed in 11,803 farms (Anagrafe Nazionale Zootecnica, 2019). To date the main problems for sheep and goat farming are still represented by parasitosis and mastitis. Clinical and more often, subclinical intramammary infections (IMI) in sheep and goats are mainly caused by coagulase-negative staphylococci (CNS) and Staphylococcus aureus. IMI caused by S. aureus warrant special attention because this aggressive, environmental bacterium is responsible for both acute-hyperacute clinical mastitis (gangrenous mastitis) and subclinical syndromes. S. aureus is a Grampositive coccal bacterium belonging to the Staphylococcaceae family. Normally it is considered, opportunistic pathogen but in the case of mastitis it often becomes highly contagious causing a rapid spread through the flock, characterized by high morbidity. The virulence of $S$. aureus depends on the production of several different factors, such as hemolysins, leukocidins, proteases, and toxins contributing to its pathogenicity. (Some S. aureus strains produce toxins, such as superantigen staphylococcal toxic shock syndrome toxin (tsst-1), staphylococcal enterotoxins (SEs), or enterotoxin-like proteins (SEl) (Balaban and Rasooly, 2000). Another important virulence factor is related to the ability of some staphylococci to produce biofilms, which affect antibiotic concentrations, allowing for bacterial multiplications within the biofilm population and increasing the chances of its survival within the host (Melchior et al., 2006). Several mechanisms such as interaction of antimicrobials with biofilm matrix components, reduced growth rates, the presence of metabolic different subpopulations are responsible for the major resistance of biofilm to antimicrobial (Hall et al., 2017). Their formation is a multifactorial event, controlled by quorum sensing and, several proteins, such as the accessory gene regulator protein (agr), the biofilm-associated protein (bap), the intercellular adhesion protein (ica), and the $S$. aureus surface protein (SasC) (Vitale et al., 2015). The ica operon is responsible for the synthesis of one of them, the intercellular adhesion protein that is an important component of the staphylococcal biofilm (Fitzpatrick et al., 2005). In the control of ovine staphylococcal mastitis, antimicrobial therapy continues to play a significant role in limiting the infection spread and moreover to prevent animal death. Antibiotic must be utilized for treatment of the first clinical cases in order to stop the excretion of the pathogen within
Correspondence: Giusi Macaluso, Institute for Experimental Veterinary Medicine of Sicily, via Gino Marinuzzi 3, 90129 Palermo, Italy. Tel.: +393497641520.

E-mail: giusi.macaluso@izssicilia.it

Key words: Staphylococcus aureus; Antimicrobial resistance; Virulence factors, Biofilm.

Acknowledgments: We thank the Italian Reference Laboratory for Coagulase positive and negative Staphylococci for the enterotoxins control strains.

Contributions: Alessio Parco and Giusi Macaluso contributed equally.

Conflict of interest: The authors declare no conflict of interest.

Funding: This work was supported by the Italian Ministry of Health (Progetto di Ricerca Corrente RC IZS SI 05/17 - Identificazione di marcatori immunologici nel latte e mammella ovina durante l'infezione e la vaccinazione contro l'agalassia contagiosa).

Availability of data and materials: All data and materials are available within the text.

Received for publication: 3 March 2021.

Revision received: 14 July 2021.

Accepted for publication: 30 August 2021.

This work is licensed under a Creative Commons Attribution-NonCommercial 4.0 International License (CC BY-NC 4.0).

(C) Copyright: the Author(s), 2021

Licensee PAGEPress, Italy

Italian Journal of Food Safety 2021; 10:9722

doi:10.4081/ijfs.2021.9722

the whole flock and to avoid contamination of the environment and/or milking machine. Nevertheless, they are too expensive for general treatment of the farm/herd whereas vaccine including autologous vaccine could be the most sustainable way to control the infection on long term. Antibiotic resistance of $S$. aureus isolates from cases of ovine mastitis has been previously described (Azara et al., 2017). Since the discovery of penicillin and related antibiotic therapy, $S$. aureus was one of the species which after only 5 years acquired the ability to grow in the presence of this antibiotic due to $\beta$-lactamase enzyme, coded at its plasmid level (Pitkala et al., 2007). Methicillin resistance was first reported by Jevons (1961) who detected only three methicillin-resistant $S$. aureus strains (MRSA) on a screening of 5,440 isolates. In the last years there was increasing attention due to the emergence of livestock-associated methicillin-resistant 
strains (LA-MRSA) (Guardabassi et al., 2013). High-level resistance to methicillin or other $\beta$-lactam antimicrobials in $S$. aureus strains is conferred by the mecA gene (Peacock and Paterson, 2015). Staphylococcal resistance to other antimicrobials such as cephalosporins, tetracyclines, erythromycin, lincomycin and kanamycin have also been recently reported (Jones et al., 2006; Guo et al., 2020; Karaman et al., 2020). High costs of modern antibiotics do not always guarantee the expected results, but they are still the only chance to stop clinical disease and moreover to avoid a massive pathogen spread in the flock. All bactericidal antibiotics could be very useful to sterilize the clinical cases at the beginning of the infection and associating proper biosecurity practices in the farm to stop the contagion. On the other hand, the use of antibiotic classified as "bacteriostatic" such as tetracyclines and macrolides, could be helpful in recovering clinical signs for a while, but after few weeks may concern the risk of a reoccurrence of the outbreak in the farm. The prolonged use of these bacteriostatic products may also drive to drug-resistance phenomena. Recently, the risk of antibiotic failure has increasingly emphasized the importance of targeted, specific treatments by identifying the most effective product to stop/resolve the outbreak. The aim of this study is to analyse the antibiotic resistance profile of $S$. aureus isolates collected from ovine milk samples in Sicily from 2006 to 2015 and to provide a contribution by updating data on mastitis antibiotic treatments in small ruminants. In addition, the isolates were studied for the presence of toxin genes and biofilm-related genes.

\section{Materials and methods}

\section{Sampling, isolation, and characteri- zation}

Eighty-four isolates of S.aureus coming from individual and/or bulk milks belonging to sheep and goat farms of different area of Sicily were tested for antimicrobial susceptibility against a panel of the most utilized antimicrobials. Eighty-one isolates of Staphylococci were obtained from milk samples of sheep or goat related to clinical mastitis and isolated during the diagnostic activity carried out at the Istituto Zooprofilattico Sperimentale della Sicilia (IZS). Three samples of S.aureus were isolated from bulk milk during auto-control programs. Milk samples were collected after cleaning and disinfection of the udders and discharge of the first milk; samples were taken at the morning by manual milking and collected in sterile vials. Milk samples were screened for the presence of mastitic pathogens including Staphylococcus spp. as well as the other pathogens which cause mastitis in small ruminants comprising, Corynebacterium spp. Streptococcus spp. and mycoplasmas. After isolation, field strains were identified through standard procedures and stored at $-80^{\circ} \mathrm{C}$ for further studies. Samples $(10 \mathrm{ml})$ were diluted with $90 \mathrm{ml}$ of buffered peptone water (Oxoid, Basingstoke, UK) and homogenized. They were seeded into Baird-Parker RPF agar (Oxoid) and incubated aerobically at $35^{\circ} \mathrm{C}$ for 24 and $48 \mathrm{~h}$. The isolates of $S$. aureus were identified using conventional biochemical methods including Gram staining, catalase test (Biomerieux), oxidase (oxidase strips Oxoid), coagulase and Test VP (Voges - Proskauer - Biomerieux). Before testing all isolates were subcultured in $10 \mathrm{ml}$ of brain-heart infusion (BHI) broth (Oxoid) for $24 \mathrm{~h}$ at $37^{\circ} \mathrm{C}$. All strains of $S$. aureus selected for this survey were isolated from 2006 to $2009\left(\delta \mathrm{T}_{1}\right)$ and from 2013 to 2015 $\left(\delta \mathrm{T}_{2}\right)$.

\section{Antimicrobial susceptibility}

Susceptibility tests were performed by disk diffusion method (Bauer et al., 1966) on Mueller-Hinton Agar (Liofilchem ${ }^{\circledR}$, Teramo, IT). Susceptibility to 19 different molecules belonging to 9 classes of antibiotics was evaluated by placing on agar plate antibiotic discs of: aminoglycosides [gentamicin $(10 \mu \mathrm{g})$, spectinomycin $(10 \mu \mathrm{g})$, streptomycin $(10 \mu \mathrm{g})$, tobramycin $(10 \mu \mathrm{g})]$; carbapenems [imipenem $(10 \mu \mathrm{g})$ ]; cephalosporins [cefepime $(30 \mu \mathrm{g})$ ]; fluoroquinolones [enrofloxacin $(5 \mu \mathrm{g})$ ]; glycopeptides [vancomycin $(30 \mu \mathrm{g})$ ]; lincosamides [lincomycin $(15 \mu \mathrm{g})]$; macrolides [erythromycin $(15 \mu \mathrm{g})$; tilmicosin $(15 \mu \mathrm{g})]$; tylosin $(30 \mu \mathrm{g})$ ]; penicillins [ampicillin $(10$ $\mu \mathrm{g})$, oxaxillin $(1 \mu \mathrm{g})]$; phenicols [florfenicol $(30 \mu \mathrm{g})]$; rifamycins [rifampicin $(30 \mu \mathrm{g})]$; sulfonamides [sulfamethoxazole $(25 \mu \mathrm{g})$ ]; tetracyclines [oxytetracycline $(30 \mu \mathrm{g})$, tetracycline $(30 \mu \mathrm{g})$ ] (Liofilchem ${ }^{\circledR}$, Teramo, IT). For investigation on antibacterial activity, the diameter of inhibition zone was measured after incubation at $37^{\circ} \mathrm{C}$ for $24 \mathrm{~h}$. Isolates were considered either susceptible (S), intermediate (I) or resistant (R) according to Clinical Laboratory Standards Institute (CLSI) guidelines (Clinical Laboratory Standards Institute-CLSI, 2017). Additionally, isolates were considered multidrug resistant (MDR) when a resistance to three or more antimicrobial classes was detected (Magiorakos et al., 2012).
The data obtained from the antimicrobial susceptibility tests were grouped into two periods intervals $\delta \mathrm{T}_{1}(2006-2009-21$ isolates) and $\delta \mathrm{T}_{2}(2013-2015$ - 63 isolates) and compared to show the behavior of the different isolates in different periods with a time interval of 5 years. Statistical analysis was carried out using T-Test to check the significance of the differences $(\mathrm{P}<0.05)$.

\section{Detection of antibiotics resistance and toxin genes}

Further genetic analysis was carried out in order to evaluate possible acquired genetic resistance. In particular, erythromycin (erm $A$ and erm $C$ ) and tetracycline (tet $K$ and tet $M$ ) resistance genes were investigated by multiplex PCR (Ardic et al., 2005). The DNA was extracted by the Instagene Matrix (Biorad) according to the manufacturer's instructions. PCRs were performed following the multiplex PCR method described by Strommenger et al. (2003). An internal control primer pair specific to $16 \mathrm{~S}$ rDNA (16S rDNA F 5'- CAG CTC GTG TCG TGA GAT GT-3, 16S rDNA R 5'- AAT CAT TTG TCC CAC CTT CG-3') was added to the multiplex PCR protocol to determine amplification effectiveness and likely PCR inhibition. The PCR mixture was prepared using PuReTaq Ready-To-Go, GE Healthcare, in $25 \mathrm{ul}$ total volume containing $0.4 \mathrm{M}$ of each primer and $21 \mu \mathrm{l}$ of water. To this mixture $2 \mu \mathrm{l}$ of extracted bacterial DNA were added. The PCR protocol consisted of 3 min of preliminary denaturation at $95^{\circ} \mathrm{C}$, 30 cycles of $30 \mathrm{~s}$ denaturation at $95^{\circ} \mathrm{C}, 30 \mathrm{~s}$ of primer binding at $54^{\circ} \mathrm{C}$ and $30 \mathrm{~s}$ of polymerization at $72^{\circ} \mathrm{C}$ followed by a final 4 min polymerization at $72^{\circ} \mathrm{C}$. Amplification products were subjected to $1.5 \%$ agarose gel electrophoresis in a fixed $100 \mathrm{~V}$ electrical field; the resulting bands for ermC, erm $A$, tet $K$, tet $M$ were examined under an ultraviolet-transilluminator

(UV Transilluminator 2000; Bio-Rad, Milan, Italy) and photographed with a Kodak digital camera. The results were grouped into two-time intervals $\delta \mathrm{T} 1(2006-2009)$ $\delta$ T2(2013-2015) and compared to show the behavior of the isolates in different periods.

The $S$. aureus isolates were also analyzed for the presence of different toxin genes and the presence of methicillin resistance mecA gene. Genes for pyrogenic toxins: staphylococcal enterotoxins (SE) from A to $\mathrm{E}$ and toxic shock syndrome toxin 1 (tsst-1) were detected by Multiplex PCR A and Exfoliative toxins eta and etb and mecA genes by Multiplex PCR B as described by Mehrotra et al. 2000. For detection of seg, seh, sei, sej, and sep, a multiplex PCR assay described by De Buyser (2009) was followed. Detection of 
fem $A$ was used as an internal positive control and $S$. aureus ATCC 25923 as quality control. The following reference strains for SE genes kindly provided by the Italian reference laboratory for Coagualse positive and negative Staphylococci were used: FRIS6 (sea, seb); FRI137 (sec, seg, seh, sei); HMPL280 (sed, seg, sei, sej, sep, ser); and FRI326 (see). The amplicons were detected using a $2.5 \%$ agarose gel containing ethidium bromide and visualized under ultraviolet light as described by Vitale et al. (2018)

\section{Detection of genes involved in biofilm formation}

Ica operon was detected with primers including a region from ica $R$ to ica $A$ (Position from 1889 to 2486 S. aureus ica operon sequence GenBank: AF086783). (Cramton et al.1999). PCRs for bap and SasC genes were performed as described by Cucarella et al. (2004) and Schroeder et al. (2009) respectively.

\section{Statistical analyses}

Statistical analysis was carried out using T-Test to check the significance of the differences $(\mathrm{P}<0.05)$ between $\delta \mathrm{T}_{1}(2006$ 2009) - $\delta \mathrm{T}_{2}(2013-2015)$.

Duplicate tests were performed on each sample by IZS of Sicily and Department of Veterinary Science of University of Messina. One-way paired T-test was used to compare multidrug resistance patterns from bacterial isolates in groups $\delta \mathrm{T}_{1}$ and $\delta \mathrm{T}_{2}$ using R (R Core Team, 2019).

\section{Results}

\section{Staphylococcus aureus antimicrobial susceptibility}

Isolates displayed high frequencies of antibiotic resistance (Table 1). The resistance patterns varied from 1 to 10 of the 19 antibiotics tested. The largest number of resistances were recorded against spectinomycin $(100 \%$ of the isolates) and streptomycin ( $86,9 \%$ of the isolates) both belonging to the aminoglycosides family. The isolates showed high susceptibility to florfenicol, imipenem, rifampicin, and tobramycin. Among the 84 isolates, 31 (36.9\%) were resistant to sulfamethoxazole, $18(21.4 \%)$ to tetracycline and $19(22.6 \%)$ to oxytetracycline and to erythromycin. Remaining isolates showed resistance lower of $20,0 \%$ to the other molecules. Multidrug resistance occurred in 26 isolates (30.9\%). The most abundant MDR pattern observed was combined resistance to aminoglycosides, macrolides and tetracyclines in 19 isolates (22.6\%). T-test revealed significant increase of the resistance to tilmicosin and decrease to sulfamethoxazole and vancomycin between the two periods intervals $(\mathrm{P}<0.05)$. Although they were not significant, the results showed as the resistances to oxytetracycline and tetracycline tend to increase between $\delta \mathrm{T}_{1}$ and $\delta \mathrm{T}_{2}$.

\section{Genotypic detection of erythromycin and tetracycline resistance genes}

Tetracycline resistance genes (TRg) were detected in 19 samples $(22.6 \%)$ (Table 2); tetK (360 bp) and tetM (158 bp) were simultaneously highlighted in almost all positive samples (17 out of 19), while no sample present only tet $M$ gene. There is a significant difference $(\mathrm{P}<0.05)$ of presence of $\mathrm{TRg}$ between $\delta \mathrm{T}_{1}(4.8 \%)$ and $\delta \mathrm{T}_{2}$ $(28,6 \%)$. Regarding the Erythromycin Resistance genes (ERg), detection rates of ermC (299 bp) were 15.5\%, only an isolate showed ermA (190 bp) resistance gene. The difference between $\delta \mathrm{T}_{1}$ and $\delta \mathrm{T}_{2}$ was only significant for erm $C$ gene. The contemporanous presence of tet $(K)$ and $\operatorname{tet}(M)$ were detected in 17 isolates $(20.5 \%)$, with significant increase between the two periods intervals (Table 2). As shown in Table 3, the contemporaneous presence of resistance genes for tetracycline and erythromycin was detected in seven samples $(8.3 \%)$, belonging to group $\delta \mathrm{T}_{2}$. The mecA was found only in one sample belonging to $\delta \mathrm{T}_{1}$ (Table 3).

\section{Detection of biofilm formation and toxin genes}

Enterotoxin genes were detected only in four isolates $(4.8 \%)$ of $\delta \mathrm{T} 2$ group while Toxic shock syndrome toxin (tsst-1) gene was present in five samples $(5.9 \%)$, all belonging to $\delta \mathrm{T} 2$ group. No exfoliative toxin gene was detected. Fifty-seven isolates $(67.9 \%)$ result positive for ica operon, thirty isolates $(35.7 \%)$ presented sas C gene. In the group $\delta \mathrm{T} 1$ eight isolates $(38.0 \%)$ are simultaneously positive for both genes while the bap gene was not present in any

Table 1. S. aureus Isolates resistance to 19 antibiotics.

\begin{tabular}{|c|c|c|c|c|c|c|c|c|c|c|}
\hline Classes & Antimicrobials & $I+R$ & $\begin{array}{c}\delta \mathrm{T}_{1} \\
\text { Total Strains }\end{array}$ & $\%$ & $I+\mathbf{R}$ & $\begin{array}{c}\delta \mathrm{T}_{2} \\
\text { Total Strains }\end{array}$ & $\%$ & $I+R$ & $\begin{array}{c}\delta \mathrm{T}_{1}+\delta \mathrm{T}_{2} \\
\text { Total Strains }\end{array}$ & $\%$ \\
\hline Aminoglycosides & $\begin{array}{l}\text { Gentamicin } \\
\text { Spectinomycin } \\
\text { Streptomycin } \\
\text { Tobramycin }\end{array}$ & $\begin{array}{c}1 \\
21 \\
19 \\
-\end{array}$ & $\begin{array}{l}21 \\
21 \\
21 \\
21\end{array}$ & $\begin{array}{c}4.8 \\
100 \\
90.5 \\
-\end{array}$ & $\begin{array}{c}1 \\
63 \\
54 \\
-\end{array}$ & $\begin{array}{l}63 \\
63 \\
63 \\
63\end{array}$ & $\begin{array}{c}1.6 \\
100 \\
85.7 \\
-\end{array}$ & $\begin{array}{c}2 \\
84 \\
73 \\
-\end{array}$ & $\begin{array}{l}84 \\
84 \\
84 \\
84\end{array}$ & $\begin{array}{c}2.4 \\
100 \\
87 \\
-\end{array}$ \\
\hline Carbapenems & Imipenem & - & 21 & - & - & 63 & - & - & 84 & - \\
\hline Cephalosporins & Cefepime & 2 & 21 & 9.5 & - & 63 & - & 2 & 84 & 2.4 \\
\hline Fluoroquinolones & Enrofloxacin & - & 21 & - & 2 & 63 & 3.2 & 2 & 84 & 2.4 \\
\hline Glycopeptides & Vancomycin & 6 & 21 & $28.6^{*}$ & 3 & 63 & $4.8^{*}$ & 9 & 84 & 10.7 \\
\hline Lincosamides & Lincomycin & 2 & 21 & 9.5 & 11 & 63 & 17.5 & 13 & 84 & 15.4 \\
\hline Macrolides & $\begin{array}{l}\text { Erythromycin } \\
\text { Tilmicosin } \\
\text { Tylosin }\end{array}$ & $\begin{array}{l}5 \\
1 \\
3\end{array}$ & $\begin{array}{l}21 \\
21 \\
21\end{array}$ & $\begin{array}{l}23.8 \\
4.8^{*} \\
14.3\end{array}$ & $\begin{array}{l}14 \\
13 \\
12\end{array}$ & $\begin{array}{l}63 \\
63 \\
63\end{array}$ & $\begin{array}{c}22.2 \\
20.6^{*} \\
19.0\end{array}$ & $\begin{array}{l}19 \\
13 \\
15\end{array}$ & $\begin{array}{l}84 \\
84 \\
84\end{array}$ & $\begin{array}{l}22.6 \\
16.7 \\
17.8\end{array}$ \\
\hline Penicillins & $\begin{array}{l}\text { Ampicillin } \\
\text { Oxaxillin }\end{array}$ & $\begin{array}{l}3 \\
1\end{array}$ & $\begin{array}{l}21 \\
21\end{array}$ & $\begin{array}{c}14.3 \\
4.8\end{array}$ & $\begin{array}{l}4 \\
-\end{array}$ & $\begin{array}{l}63 \\
63\end{array}$ & $\begin{array}{c}6.3 \\
-\end{array}$ & $\begin{array}{l}7 \\
1\end{array}$ & $\begin{array}{l}84 \\
84\end{array}$ & $\begin{array}{l}8.3 \\
1.2\end{array}$ \\
\hline Phenicols & Florfenicol & - & 21 & - & - & 63 & - & - & 84 & - \\
\hline Rifamycins & Rifampicin & - & 21 & - & - & 63 & - & - & 84 & - \\
\hline Sulfonamides & Sulfamethoxazole & 15 & 21 & $71.4^{*}$ & 16 & 63 & $25.4^{*}$ & 31 & 84 & 36.9 \\
\hline Tetracyclines & $\begin{array}{l}\text { Oxytetracycline } \\
\text { Tetracycline }\end{array}$ & $\begin{array}{l}3 \\
2\end{array}$ & $\begin{array}{l}21 \\
21\end{array}$ & $\begin{array}{c}14.3 \\
9.5\end{array}$ & $\begin{array}{l}16 \\
16\end{array}$ & $\begin{array}{l}63 \\
63\end{array}$ & $\begin{array}{l}25.4 \\
25.4\end{array}$ & $\begin{array}{l}19 \\
18 \\
\end{array}$ & $\begin{array}{l}84 \\
84 \\
\end{array}$ & $\begin{array}{l}22.6 \\
21.4\end{array}$ \\
\hline
\end{tabular}

Strains resulted intermediates and resistant $(\mathrm{I})+(\mathrm{R})$ grouped in two intervals $\delta \mathrm{T}_{1}(2006-2009)$ and $\delta \mathrm{T}_{2}(2013-2015)$. ${ }^{*} \mathrm{P}$-value $<0.05-\mathrm{T}$-test was performed for comparisons of the resistance among $\delta \mathrm{T}_{1}$ and $\delta \mathrm{T}_{2}$. 
isolate. No significant differences $(\mathrm{P}>0.05)$ were observed between the two groups (Table 4).

\section{Discussion}

Staphylococcus aureus is a main responsible for mastitis in ruminant herds with big economic loss in dairy farms due to lower or absent milk production. In this study several S.aureus isolates from clinical mastitis cases showed resistance to different antibiotics and a prevalence of multidrug resistant strains $(30.9 \%)$ much higher than those reported in previous studies (Azara et al., 2017; Zdragas et al., 2015). Moreover, according to other reports (Rajala-Schultz et al., 2004; Ceniti et al., 2017), a high resistance and multiresistance for Tetracycline, Macrolides and Sulfamethoxazole was observed, although these molecules are not specifically prescribed for the treatment of Gram-positive, bacterial mastitis. The significant increase of tilmicosin resistance, between $\delta \mathrm{T}_{1}$ $(4.8 \%)$ and $\delta \mathrm{T}_{2}(20.6 \%)$, suggests an increasing use of this antibiotic in the health management of small ruminant farms in Sicily.
The low percentage of resistance to oxacillin and enrofloxacin is consistent with the results obtained by other authors (Zdragas et al., 2015; Ceniti et al., 2017). Moreover, all isolates showed susceptibility to florfenicol, imipenem, rifampicin and tobramycin suggesting that these antibiotics are not used in a routine basis in Sicilian small ruminant farming. No correlation was found between the isolates resistant to $\beta$-lactams and tetracycline classes, according with previous studies conducted on $S$. aureus isolates isolated from raw sheep milk and /or cheese samples (Spanu et al., 2014). Despite a variety of available antibiotics, success of treatment of $S$. aureus mastitis particularly during lactation is argued (Pengov and Ceru, 2003). Clearly, there are several factors that influence the outcome of the therapy. Bacterial strains resistant to antimicrobial agents used in mastitis treatment might be one of the important reasons for therapy failure. Thus, information on susceptibility trends for a bacterial species within a given population is important. Antimicrobial susceptibility testing of the causal pathogens should help to identify the most appropriate treatment for therapy of mastitis. The mecA gene was detected only in one of the $S$. aureus isolates studied. In this study, the mecA gene was detected in one of the $S$. aureus strains only in contrast to a mecA positive prevalence of $4.5 \%$ detected in $S$. aureus isolated from food sources (Vitale et al., 2018), mainly derived from cow-milk of Ragusa province where a higher prevalence of $m e c A$ has been detected in people working in bovine farms (Antoci et al., 2013). This result agrees also with what was found in other studies on small ruminants (Vyletelová et al., 2011; Virdis et al., 2010; Kotzamanidis et al., 2021) and confirms low prevalence of MRSA in sheep and goats' milk (Caruso et al., 2016) and dairy products (Basanisi et al., 2016). The high presence of $\operatorname{tet}(K)$ and $\operatorname{tet}(M)(20.5 \%)$ suggests an overuse of broad-spectrum antibiotics such as tetracyclines in sheep and goat diseases. Moreover, only in $\delta \mathrm{T} 2$ group, the $11.1 \%$ of the samples present a simultaneous presence of TRg and ERg. Not always there is correspondence between the presence of tet and erm genes and phenotypic resistance to related antimicrobials as found by Ardic (2005) and Sekiguchi (2003). It's possible to hypothesize that resistance to these antibiotics may depend on different mechanisms as found by other authors (Mathews et al. 2010). Maybe different bacterial pathways are

Table 2. Presence of resistance genes tetK, tetM, ermA, erm $C$, with the corresponding phenotypic antibiotic resistance.

\begin{tabular}{|c|c|c|c|c|c|c|c|c|}
\hline & T.R.g ${ }^{1}$ & $\%$ & $t_{e t} K^{2}$ & $\%$ & $\operatorname{tet}^{3}{ }^{3}$ & $\%$ & $\operatorname{Tet}(K)+\operatorname{Tet}(M)^{6}$ & $\%$ \\
\hline$\delta \mathrm{T}_{1}$ & $1 / 21$ & 4.7 & $0 / 21$ & - & $0 / 21$ & - & $1 / 21$ & 4.7 \\
\hline$\delta \mathrm{T}_{2}$ & $18 / 63$ & 28.6 & $2 / 63$ & 3.2 & $0 / 63$ & - & $16 / 63$ & $25.4^{*}$ \\
\hline Total & $19 / 84$ & 22.6 & $2 / 83$ & 2.4 & $0 / 84$ & - & $17 / 83$ & 20.5 \\
\hline & E.R.g ${ }^{1}$ & $\%$ & erm $A^{4}$ & $\%$ & erm $C^{5}$ & $\%$ & $\operatorname{Erm}(A)+\operatorname{Erm}(C)^{6}$ & $\%$ \\
\hline$\delta \mathrm{T}_{1}$ & $1 / 21$ & 4.7 & $1 / 21$ & 4.7 & $0 / 21$ & - & $0 / 21$ & - \\
\hline$\delta \mathrm{T}_{2}$ & $12 / 63$ & 19 & $0 / 63$ & - & $12 / 63$ & $19 *$ & $0 / 63$ & - \\
\hline Total & $13 / 84$ & 15.5 & $1 / 84$ & 1.2 & $12 / 84$ & 14.3 & $0 / 84$ & - \\
\hline
\end{tabular}

'Presence of at least one resistance gene, ${ }^{2}$ Presence of the only gene tetK, ${ }^{3}$ Presence of the only gene tetM, ${ }^{4}$ Presence of the only gene ermA, ${ }^{5}$ Presence of the only gene ermC, ${ }^{6}$ Presence of both genes,. T-test was performed for comparisons of the resistance among $\delta \mathrm{T}_{1}$ and $\delta \mathrm{T}_{2} *{ }^{*}$-value $<0.05$.

Table 3. Presence of resistance genes for tetracycline (TRg) and erythromycin (ERg) and of mecA gene.

\begin{tabular}{lccccc} 
Samples & $T \operatorname{Rg}+\operatorname{Erg}$ & $\%$ & $m e c A$ & $\%$ & 4.8 \\
$\delta \mathrm{T}_{1}$ & $0 / 21$ & - & $1 / 21$ & - \\
$\delta \mathrm{T}_{2}$ & $7 / 63$ & 11.1 & $0 / 63$ & 1.2 \\
\hline Total & $7 / 84$ & 8.3 & $1 / 84$ & \\
\hline
\end{tabular}

Table 4. Presence of different biofilm formation genes in Staphylococcus aureus isolates.

\begin{tabular}{|c|c|c|c|c|c|c|}
\hline Samples & ica operon & $\%$ & sas $C$ & $\%$ & Bap & $\%$ \\
\hline $\mathrm{T} 1$ & $14 / 21$ & 66.7 & $9 / 21$ & 42.9 & $0 / 21$ & - \\
\hline $\mathrm{T} 2$ & $43 / 63$ & 68.3 & $21 / 63$ & 33.3 & $0 / 63$ & - \\
\hline Total & $57 / 84$ & 67.9 & $30 / 84$ & 35.7 & $0 / 84$ & - \\
\hline
\end{tabular}


used to reach resistance. We cannot exclude also that Single-Nucleotide Polymorphisms (SNP) at level of the primer's sequences are responsible for the lack of amplification in some cases. To this end, and to fully characterize the isolates, whole genome sequencing analysis are planned for the future studies.

IMI caused by $S$. aureus may concern severe implications for public health because of the risk of enterotoxins production and toxic shock syndrome toxin (Balaban and Rasooly, 2000). In contrast with previous studies conducted on S.aureus strains isolated from bulk-tank milk samples of goats and sheep (Scherrer et al., 2004) and on isolates from dairy products and tissue samples in Sicily the prevalence of toxin genes detected in the present study was not particularly high. However, increased in $\delta \mathrm{T}_{2}$ group suggesting the possibility that toxigenic $S$. aureus isolates are spreading with the time in animal herds. In a previous report in Greece the presence of the staphylococcal enterotoxin C (SEC) was more related to the mastitis milk (Kotzamanidis et al., 2021). Exfoliative toxins genes were not detected, according with previous studies on $S$. aureus isolates from bovine mastitis (Endo et al., 2003; Vitale et al., 2019). The high involvement of $S$. aureus in IMI may concern severe implications for public health and food safety because of the risk of enterotoxins production and toxic shock syndrome toxin (Balaban and Rasooly, 2000). In subclinical inflammation milk production is almost normal and S.aureus can be transmitted into the dairy food chain, leading to contaminated dairy products, particularly when they are made with raw milk like in traditional and artisanal cheese. Staphylococcal enterotoxins (SEs) are a major cause of food poisoning world-wide (Agurdin et al., 2010; Mehli et al., 2017). Biofilm formation in strains from cases of sheep and goats is a poorly investigated aspect if compared with other virulence factors. According to Tel (2012) the ica operon was detected with high percentage $(67.9 \%)$ and the bap gene was not present in any isolates. These data may justify how, in cases of sheep and goat mastitis, the ability of $S$. aureus to resist against therapy by forming biofilm is mainly mediated by the ica operon.

\section{Conclusions}

This study showed that there is a high prevalence of MDR in S.aureus isolates collected in Sicily from mastitic milks of small ruminants, with an increase of resistance to broad spectrum antibiotic, as tetracyclines. This "commercial" induced resistance is proved by the evidence to find $\beta$-lattamines susceptible strains of Staphylococcus showing resistance to tetracyclines. It suggests that an evaluation of antimicrobial susceptibility is always recommended before treating the flock. Products like florfenicol, rifampicin, tobramycin or imipenem are not all registered for veterinary use because of the risk to introduce AMR in food of animal origin. In addition, the high cost of herd or flock treatment is not sustainable for the farming economy in Sicily especially for small ruminants. Florfenicol has been recently introduced in Veterinary practice mainly addressed to respiratory syndromes of cattle and/or pets and its cost is justified if related to the loss of one calf or to welfare of companion animals. An increase in toxigenic potential was highlighted by the presence of sec, tsst- 1 genes in some isolates of $\delta \mathrm{T}_{2}$ group. Biofilm-forming ability could be another important virulence factor of $S$. aureus strains which underlines the importance of cleaning and disinfection of milking parlour, equipment, and the other farm facilities and moreover, the responsibility by farmer to implement biosecurity practices.

\section{References}

Anagrafe Nazionale Zootecnica, 2019. Ministero della Salute Italiana. Avallabile from: https://www.vetinfo.it/j6_statistiche/\#/r eport-pbi/29.

Argudín MÁ, Mendoza MC, Rodicio MR, 2010. Food poisoning and Staphylococcus aureus enterotoxins. Toxins (Basel) 2:1751-73.

Antoci E, Pinzone MR, Nunnari G, Stefani S, Cacopardo B, 2013. Prevalence and molecular characteristics of methicillinresistant Staphylococcus aureus (MRSA) among subjects working on bovine dairy farms. Infez Med 21:1259.

Ardic N, Ozyurt M, Sareyyupoglu B, Haznedaroglu T, 2005. Investigation of erythromycin and tetracycline resistance genes in methicillin-resistant staphylococci. Int J Antimicrob Agents 26:213-8

Azara E, Piras MG, Parisi A, Tola S, 2017. Antimicrobial susceptibility and genotyping of Staphylococcus aureus isolates collected between 1986 and 2015 from ovine mastitis. Vet Microbiol 205:53-6.

Balaban N, Rasooly A, 2000. Staphylococcal enterotoxins. Int J Food Microbiol 61:1-10.

Basanisi MG, Nobili G, La Bella,G, Russo
R, Spano G, Normanno G, La Salandra G, 2016. Molecular characterization of Staphylococcus aureus isolated from sheep and goat cheeses in southern Italy. Small Rum Res 135:17-9.

Bauer AW, Kirby WMM, Sherris JC, Turck M, 1966. Antibiotic susceptibility testing by a standardized single disk method. Am J Clin Pathol 45:493-6.

Caruso M, Latorre L, Santagada G, Fraccalvieri R, Miccolupo A, Sottili R, Palazzo L, Parisi A, 2016. Methicillinresistant Staphylococcus aureus (MRSA) in sheep and goat bulk tank milk from Southern Italy. Small Rum Res 135:26-31.

Ceniti C, Britti D, Santoro AML, Musarella $\mathrm{R}$, Ciambrone L, Casalinuovo F, Costanzo N, 2017. Phenotypic antimicrobial resistance profile of isolates causing clinical mastitis in dairy animals. Ital J Food Saf 13:6612.

Hall CW, Mah T, 2017. Molecular mechanisms of biofilm-based antibiotic resistance and tolerance in pathogenic bacteria. FEMS Microbiol Rev 41:276-301.

Clinical Laboratory Standards Institute CLSI, 2017. Performance Standards for Antimicrobial Susceptibility Testing. Twenty-Seventh Informational Supplement. CLSI document M100S. Wayne, Pennsylvania, USA.

Cramton SE, Gerke C, Schnell NF, Nichols WW, Gotz F, 1999. The intercellular adhesion (ica) locus is present in Staphylococcus aureus and is required for biofilm formation. J Infect Immun 67:5427-33.

Cucarella C, Tormo MA, Ubeda C, Trotonda MP, Monzon M, Peris C, Amorena B, Lasa I, Penades JR, 2004. Role of biofilm-associated protein Bap in the pathogenesis of bovine Staphylococcus aureus. Infect Immun 72:2177-85.

De Buyser ML, Grout J, Brisabois A, Assere A, Lombar B, 2009. Detection of genes encoding staphylococcal enterotoxins. Multiplex PCR for seg to sej and sep. Method of the CRL for coagulase positive staphylococci including Staphylococcus aureus. Version 1. CRL CPS, Maisons-Alfort, France.

Endo Y, Yamada T, Matsunaga K, Hayakawa Y, Kaidoh T, Takeuchi S, 2003. Phage conversion of exfoliative toxin A in Staphylococcus aureus isolated from cows with mastitis. Vet Microbiol 8:81-90.

Fitzpatrick F, Humphereys H, O'Gara JP, 2005. Evidence for ica ADBC-independent biofilm development mechanism in methicillin-resistant Staphylococcus 
aureus clinical isolates. J Clin Microbiol 43:1973-6.

Guardabassi L, Larsen J, Weese JS, Butaye P, Battisti A, Kluytmans J, Lloyd DH, Skov RL, 2013. Public health impact and antimicrobial selection of meticillin-resistant staphylococci in animals. J Glob Antimicrob Resist 1:55-62.

Guo Y, Song G, Sun M, Wang J, Wang Y, 2020. Prevalence and Therapies of Antibiotic-Resistance

Staphylococcus aureus. Front Cell Infect Microbiol 10:107.

Jevons PM 1961. "Celbenin" $\square$ resistant staphylococci. Br Med J 1:124 $\square 5$.

Jones TF, Creech CB, Erwin P Baird SG, Woron AM, Schaffner W, 2006. Family outbreaks of invasive community-associated methicillinresistantStaphylococcus aureus infection. Clin Infect Dis 42:76-8.

Karaman R, Jubeh B, Breijyeh Z, 2020. Resistance of Gram-Positive Bacteria to Current Antibacterial Agents and Overcoming Approaches. Molecules 23:2888.

Kotzamanidis C, Vafeas G, Giantzi V, Anastasiadou S, Mygdalias S, Malousi A, Loukia E, Daniel S, Zdragas A, 2021. Staphylococcus aureus Isolated from Ruminants with Mastitis in Northern Greece Dairy Herds: Genetic Relatedness and Phenotypic and Genotypic Characterization. Toxins 13:176.

Magiorakos AP, Srinivasan A, Carey RB, Carmeli Y, Falagas ME, Giske CG, Harbarth S, Hindler JF, Kahlmeter G, Olsson-Liljequist B, Paterson DL, Rice LB, Stelling J, Struelens MJ, Vatopoulos A, Weber JT, Monnet DL, 2012. Multidrug-resistant, extensively drug-resistant and pandrug-resistant bacteria: an international expert proposal for interim standard definitions for acquired resistance. Clin Microbiol Infect 18:268-81.

Mathews AA, Thomas M, Appalaraju B, Jayalakshmi J, 2010. Evaluation and comparison of tests to detect methicillin resistant S. aureus. Indian J Pathol Microbiol 53:79-82.

Mehli L, Hoel S, Thomassen BGM, Jakobsen AN, Karlsen H, 2017. The prevalence, genetic diversity and antibiotic resistance of Staphylococcus aureus in milk, whey, and cheese from artisan farm dairies. Int Dairy J 65:20-7.

Melchior MB, Vaarkamp H, FinkGremmels, J, 2006. Biofilms: a role in recurrent mastitis infections?. Vet J 171:398-407.
Mehrotra M, Wang G, Johnson WM, 2000. Multiplex PCR for detection of genes for Staphylococcus aureus enterotoxins, exfoliative toxins, toxic shock syndrome toxin 1 , and methicillin resistance. J Clin Microbiol 38:1032-5.

Peacock SJ, Paterson GK, 2015. Mechanisms of Methicillin Resistance in Staphylococcus aureus. Ann Rev Biochem 84:577-601.

Pengov A, Ceru S, 2003. Antimicrobial drug susceptibility of Staphylococcus aureus strains isolated from bovine and ovine mammary glands. J Dairy Sci 86:3157-63.

Pitkala A, Salmikivi L, Bredbacka P, Myllyniemi AL, Koskinen MT, 2007. Comparison of tests for detection of beta-lactamase-producing staphylococci. J Clin Microbiol 45:2031-3.

$\mathrm{R}$ Core Team, 2019. R: A language and environment for statistical computing. R Foundation for Statistical Computing, Vienna, Austria. URL https://www.Rproject.org/.

Rajala-Schultz PJ, Smith KL, Hogan JS, Love BC, 2004. Antimicrobial susceptibility of mastitis pathogens from first lactation and older cows. Vet Microbiol 102:33-42.

Scherrer D, Corti S, Muehlherr JE, Zweifel C, Stephan R, 2004. Phenotypic and genotypic characteristics of Staphylococcus aureus isolates from raw bulk-tank milk samples of goats and sheep. Vet Microbiol 101:101-7.

Schmitz FJ, Krey A, Sadurski R, Verhoef J, Milatovic D, Fluit AC; European SENTRY Participants, 2001. Resistance to tetracycline and distribution of tetracycline resistance genes in European Staphylococcus aureus isolates. J Antimicrob Chem 47:239-40.

Schroeder K, Jularic M, Horsburgh SM, Hirschhausen N, Neumann C, Bertling A, Schulte A, Foster S, Kehrel BE, Peters G, Heilmann C, 2009. Molecular characterization of a novel Staphylococcus aureus surface protein (SasC) involved in cell aggregation and biofilm accumulation. PLoS One 4:e7567.

Sekiguchi J, Fujino T, Saruta K, Kawano F, Takami J, Miyazaki H, Kuratsuji T, Yoshikura H, Kirikae T, 2003. Spread of erythromycin-, tetracycline-, and aminoglycoside-resistance genes in methicilin-resistant Staphylococcus aureus clinical isolates in Kumamoto hospital. Jpn J Infect Dis 56:133-213.

Strommenger B, Kettlitz C, Werner G, Witte W, 2003. Multiplex PCR assay for simultaneous detection of nine clinically relevant antibiotic resistance genes in Staphylococcus aureus. J Clin Microbiol 41:4089-94.

Spanu V, Scarano C, Cossu F, Pala C, Spanu C, De Santis EP, 2014. Antibiotic resistance traits and molecular subtyping of Staphylococcus aureus isolated from raw sheep milk cheese. J Food Sci 79:2066-71.

Tel OY, Aslantaş O, Keskin O, Yilmaz ES, Demir C, 2012. Investigation of the antibiotic resistance and biofilm of Staphylococcus aureus strains isolated from gangrenous mastitis of ewe. Acta Vet Hung 60:189-97.

Virdis S, Scarano C, Cossu F, Spanu V, Spanu C, De Santis EP, 2010. Antibiotic Resistance in Staphylococcus aureus and Coagulase Negative Staphylococci Isolated from Goats with Subclinical Mastitis. Vet Med Int 517060

Vitale M; Scatassa ML; Cardamone C; Oliveri G; Piraino C, Alduina R; Napoli C, 2015. Staphylococcal Food Poisoning Case and Molecular Analysis of Toxin Genes in Staphylococcus aureus Strains Isolated from Food in Sicily, Italy. Foodborne Pathog Dis 12:21-3.

Vitale M, Gaglio S, Galluzzo P, Cascone G, Piraino C, Di Marco Lo Presti V, Alduina R, 2018. Antibiotic resistance profiling, analysis of virulence aspects and molecular genotyping of Staphylococcus aureus isolated in Sicily, Italy. Foodborne Pathog Dis 15:3.

Vitale M, Galluzzo P, Buffa PG, Carlino E, Spezia O, Alduina R, 2019. Comparison of Antibiotic Resistance Profile and Biofilm Production of Staphylococcus aureus Isolates Derived from Human Specimens and Animal-Derived Samples. Antibiotics 8:97.

Vyletelová M, Vlková H, Manga I, 2011. Occurrence and characteristics of methicillin resistant Staphylococcus aureus and methicillin resistant coagulase-negative staphylococci in raw milk manufacturing. Czech J Food Sci 29:116.

Zdragas A, Papadopoulos T, Mitsopoulos I, Samouris G, Vafeas G, Boukouvala E, Ekateriniadou L, Mazaraki K, Alexopoulos A, Lagka V, 2015. Prevalence, geneticdiversity, and antimicrobial susceptibility profiles of Staphylococcus aureus isolated from bulk tank milk from Greek traditional ovine farms. Small Rumin Res $125: 120-6$ 